\title{
DE ORANJEBOND VAN ORDE EN ZIJNE STICHTINGEN, EN IETS OVER MEERDERE VEREENIGINGEN VAN DIEN AARD.
}

In Augustus jl. bracht ik in het liefelijke, steeds in bloei en fraaiheid van aanleg toenemende A peld oorn, dat ik sedert een vorig bezoek zeer rooruit gegaan vond, eenige genoegelijke dagen door. Met den n.00 duidelijken, vau goede kaarten en plaunen voorzienen "Reisgids voor Apeldoorn en omstreken" en Cordes' keurig boekje "In Oranjes Lusthof", zoo uitstekend geschikt on $\mathrm{u}$ de schoonheden van het heerlijke Loopark recht te doen genieten ${ }^{1}$ ), in de hand, doorkruiste ik dagen lang dat overschoone, zoo fraai, net zooveel smaak aangelegde Park en een deel der Soerensche bosschen. Ik overtuigde mij op nieuw dat, -al moge ons goede landje geen trotsche Alpennatuur te aanschouwen geven, het den wandelaar, die een open oog heeft voor natuurschoon, toch veel kan doen genieten.

Mijn bezoek aan Apeldoorn had echter nog een nevendoel.

1) De lezing van dat boekje deed bij mij op nieuw den wensch ontstaan dat de heer Cordes, die ons uit den rijken schat zijner annteekeningen en herinneringen in «de Indische Gids» reeds zon menig treffend beeld geschetst had van hetgeen Ned.-Indië den bewonderaar van natuurschoon te genieten geeft, daarmede mocht voortgaan. Hij zeide mij echter te meenen dat hij op dat gebied al genoeg had gegeven, wat ik niet met hem eens was. Maar hij zeide mij tevens dat hij eerlang naar Nijmegen zou verhuizen. Ik vlei mij daarom met het vooruitzicht dat, wanneer hij zich goed in die. Nijmeegsche natuur met haar eigenaardig karakter zal hebben ingewerkt, wij van hem daarover een boekje zullen ontvangen, welks lezing het genot van den bezoeker dier streek zeer zal verhoogen omdat zijne aandacht gevestigd wordt op menige bijzonderheid, welke hij anders achteloos voorbij zoude gaan.

ECoN. 1896. 
Ik had het een en ander gelezen over de stichtingen van den "Oranjebond van Orde" aldaar, het Hofveld en de Ericastichting, en wenschte daarmede nader kennis te maken.

Mij, oud-Voorzitter-Commissaris der Maatschappij van Weldadigheid, interesseerde het eenigszins van naderbij bekend te worden met stichtingen, welke eenigermate hetzelfde beoogen als door die Maatschappij wordt beoogd.

De eigenlijke vader dier stichtingen, de man die den Oranjebond van Orde bereid vond hem in de gelegenheid te stellen zijne denkbeelden tot nitvoering te brengen, is de heer P. B. BruiJn van Rozenburg. Deze, gepensioneerd Luit.-Kolonel van het O.-I. leger, had na zijn terugkeer in het vaderland in 1880 jaren lang in de buurt van Apeldoorn den landbouw uitgeoefend. Meer en meer vestigde zich bij hem de overtuiging dat heidevelden, inzonderheid die in de buurt van Apeldoorn, met vrucht zouden kunnen worden ontgonnen; dat het uit een philanthropisch, economisch en hygiënisch oogpunt gewenscht zou zijn den arbeider uit de steden of grootere plattelandsgemeenten in de gelegenheid te stellen zich in de nabijheid der gemeente, waar hij zijn bedrijf uitoefent, op het land te vestigen, waar hij eene goede woning ${ }^{1}$ ) en een stuk gedeeltelijk toebereiden grond zou vinden, welks opbrengst tot vermeerdering zijner inkomsten zou strekken, terwijl, last not least, hem tevens het vooruitzicht werd geopend na een zeker getal jaren den onbezwarden eigendom van huis en hof te verkrijgen.

Gelijk gezegd is, werd de heer Bruijn van Rozenburg in de gelegenheid gesteld zijn denkbeelden tot uitwoering te brengen. $\mathrm{Hij} \mathrm{had} \mathrm{de} \mathrm{goedheid} \mathrm{mij} \mathrm{alle} \mathrm{verlangde} \mathrm{inlichtingen} \mathrm{te} \mathrm{geven,}$ mij op de tochten naar Hofveld en Ericastichting te vergezellen en tal van stukken ter mijner beschikking te stellen, waarin over den Oranjebond van Orde en zijne stichtingen sprake is. Later mocht ik nog, op mijne aanvrage, van 's Bonds

1) $O p$ het veelzijdig nut eener wezenlijk goede woning voor den werkman, ten einde hem aan zijn huis te boeien, wordt door hem voortdurend gewezen. Zie o. a. meerdere artikelen in de *Niellwe Apeldoornsche Courant» van Juli en Angustus 1893. 
tegenwoordigen Voorzitter, Jhr. J. Hora Siccama van de Harkstede, te Driebergen, eenige stukken ontvangen, en daaronder het op de algemeene vergadering van den Bond van 23 Mei ') uitgebrachte Jaarverslag over 1895, het eerste dat in dien vorm werd opgemakt en gedrukt, en welks lezing zeer nuttig is om met het streven en de verrichtingen van den Bond bekend te worden.

Naar aanleiding van een en ander wensch ik daarover eenige mededeelingen te doen, omdat het mij voorkomt dat het hier eene uit een sociaal economisch oogpunt belangrijke proef geldt, welke wel waard is dat er ook in dit tijdschrift meer uitdrukkelijk dan door eene korte vermelding nu en dan in de "Economische kroniek" de aandacht op worde gevestigd.

Onze taak ware gemakkelijker geweest zoo we ook voor de beide eerste jaren van het bestaan van den Oranjebond van Orde uit jaarverslagen hadden kunnen putten. Maar deze ziju niet ter onzer beschikking kunnen worden gesteld. Om eenigszins eene voorstelling te krijgeu van hetgeen die bond beoogt en tot stand bracht, moest dus, althans wat de beide eerste jaren betreft, worden geput uit den stapel der te onzer beschikking gestelde stukken.

Het orgaan van den, den $25^{\text {sien }}$ Februari 1893 opgerichten, te Utrecht gevestigden "Oranjebond van Orde" is het weekblad "Sta Pal!", hoofdredacteur Jhr J. Hora Siccama van de Harkstede, anvankelijk penningmeester, thans voorzitter van den bond. Ain het hoofd van meerdere der vroegere nummers vall dat weekblad, uitvoerig o. a. in $n^{\circ} 33$ van 3 Februari 1594 , werd het doel van den Bond omschreven. Thans, blijkens art. a der op 14. December 1895 gewijgigde statuten, luilt die omschrijving aldus: "Doel van den Bond is te trachten naar "verbetering van matschappelijke toestanden door: a. De re"geering te steunen in haar streveu naar ontwikkeling en "bevestiging vau hetgeen de beschaving, het geluk en de wel"vaart der natie verhoogen kan; 7 . Pogingen in het werk te "stellen om de moreele en stoffelijke belangen van de minder "gegoeden te behartigen en te bevorderen," o. a., blijkens $c$

1) Voor het op die vergadering beslotene, zie men «Sta Pal!» van 30 Mei jl. 
en $d$ van art. 3: "door den bouw van arbeiderswoningen" en door "heide-ontgiuning en stichting van heide-hoeven."

$\mathrm{W}_{\mathrm{ij}}$ wenschen voornamelijk te wijzen op hetgeen de Bond deed voor heideontginning en den bouw van arbeiderswoningen. Vooraf zij er echter nog op gewezen dat de beginselen van den Bond telkens met warmte in "Sta Pal!" verdedigd worden door den heer Siccama en in dat Weekblad, in de "Nieuwe Apeldoornsche Courant" en vele andere bladen door den heer Bruijn van Rozenburg, die geen enkele te zijner kennis gekomen aanmerking onbeantwoord laat. Uit dat alles blijkt dat de Bond steeds streeft naar verbetering van sociale toestanden. "Sociaal, maar antisocialistisch" heette de nieuwe hoofdredacteur van het "Dagblad van Z. H. en 's Gravenhage" 's Bonds streven in zijn nummer van 26 Juni jl. ${ }^{1}$ ) vermeldende wat de Bond reeds tot stand bracht, en de heer van Vredenburch kon het weten, omdat hij, ook al woont hij niet meer in Utrecht, in "s Bonds bestuur zitting heeft blijven houden. Het "Dagblad" van $2 S$ Juni uam uit "Sta Pal!" het bericht over dat de Bond de vereeniging "Huis en Hof" in 't leven had geroepen om bij Amersfoort 25 arbeiderswoningen à f 1200 p. p., elke afzonderlijk staande op $500 \mathrm{M}^{2}$ grond, "Z0o mogelijk met eigendomsverkrijging", te bouwen. En in "Sta Pal" van $25 \mathrm{Juli}^{2}$ ) kou men lezen dat de Bond voor dien bouw eene obligatieleening van f 30000 wenschte te sluiten. Dezer dagen werd bericht dat onze zeer geëerbiedigde Koningin-Regentes, die reeds bijgedragen had om den bouw der wouningen op het Hofveld mogelijk te maken, thans ook deze nieuwe onderneming steunde en dus toonde het streven van den Bond te wardeeren.

Zien wij nu meer bepaald wat de Bond bij Apeldoorn tot stand bracht.

Aau den Aruhemschen Straatweg, op het Hofveld en het Hattemsche veld, op 20 minuten afstands van de kom van het dorp, werden 32 hectaren heidegrond gekocht. Daarop werden, voor $f 750$ per stuk van goede materialen 32 goed ingerichte arbeiderswoningen gebouwd. ${ }^{3}$ ) Aan elke woning

1) Zie dat artikel overgenomen in «Sta Pal!» van 4 Juli.

$\left.{ }^{2}\right)$ Zie meer daarover in «Sta Pal!" van 27 Juni, 4, 11, 17 en 25 Juli.

3) Zie eene afbeelding en beschrijving van zulke wouing o. a. 
werd één hectare grond toegevoegd, waarvan $\frac{1}{5}$ gedeelte door den bond in bebouwbaren toestand gebracht en bemest werd. Die woningen werden, naarmate zij gereed kwamen en zijn thans alle bewoond door Apeldoornsche arbeidersgezinnen. De oprichters wisten dat een gezin niet van de opbrengst van 1 hectare heidegroud zonde kunnen leven, en ook niet het gansche jaar door daarop genoegzamen arbeid zou vinden. Het streven was, overeenkornstig het doel van den Bond, aan geschikte arbeidersgezinnen voor weinig geld eene goede, gezonde woning te verschaffen en gelegenheid om uit de opbrengst van den daarbij behoorenden grond hunne inkomsten te vermeerderen en hun, dat was een doel dat de heer Bruijn van Rozenburg, de eigenlijke vader der stichting op het Hofveld, steeds voor oogen hield, het vooruitzicht te openen eenmaal den onbezwaarden eigendom van huis en hof te verkrijgen. Ter voorkoming van het door sommigen gevreesd bezwaar dat de stichting Hofveld ') behoeftigen naar Apeldoorn zou lokken, werd o. a. het volgende bepaald. Niemand $\mathrm{kwam}$ voor eene plaatsing in aanmerking, tenzij hij bewees minstens twee jaren ingezeten van Apeldoorn te zijn geweest en als vaste arbeider in fabriek of werkplaats zijn dagelijksch brood te verdienen. Onder de sollicitanten werden de meest geschikten uitgekozen. Alsvorens de woning te betrekken onderteekenen zij eene hypothecaire schuldbekentenis, waarbij zij erkenden aan den Bond of anderen geldschieter f 1000 schuldig te zijn en aannemen daarvoor, in wekelijksche afbetalingen van 78 it 79 cents, eene rente van 1 p 1 Ct. of $f 40$ 's jaars te zullen betalen. Hoe men tot die som van f $1000 \mathrm{kwan}$, zien wij o. a uit een stukje van den heer Bruijn van Rozenburg in het "Geillustreerd Volksblad voor Nederland" van 31 Januari 1895, waaruit het volgende wordt overgenomen omdat daardoor de zaak duidelijk wordt beschreven. ${ }^{2}$ )

in «Geillustreerd Volksblad» en «Alg. Handelsblad» van 7 Februari en 21 April 1895.

1) Onder dien naam begrijpen wij ook de aangrenzende, geheel gelijksoortige stichting op het Hattemsche veld.

3) Dit geschiedde 0. a. ook reels in "Sta Pal!" van 14 Oct. 1893, in onderscheiden artikelen, in dat blad van 25 Nov. '93, enz., in de «Wereldkroniek» van 14 April 1894, in «de Veldpost» van 23 Juni '94, in het «Handelsblad» van 21 April '95, enz. 
"Werd mij f 1000 toevertrouwd, dan kocht ik op naam van "het hoofd van 't gezin dat daarvoor was aangewezen of in "aanmerking kwam, $1 \mathrm{H}$. heidegrond voor $\mathrm{f} 100$ en liet daar/van $\frac{1}{5}$, diep spitten en met kunstmest bewerken voor $f 50$. "Ik liet op dienzelfden naam een huis bouwen voor $\mathrm{f} 750$, "van $7 \mathrm{M}$. diep en $6 \mathrm{M}$. breed onder de kap $=42 \mathrm{M}^{2}$ opper"vlakte, waarin 2 kamers met slaapplaatsen en kasten, kelder, "zolder (die ook gedeeltelijk als slaapkamer kan dienen), achterhuis "met stalling voor klein vee, en buiten, tegen den achtermuur een "varkenshok, een overdekte mestvaalt en privaat. Alles van duur"zaam materiaal en deugdelijke constructie ${ }^{1}$ ). $\mathrm{Nu}$ is er nog "f 100 beschikbaar. Wanneer hiervan de onvermijdelijke kosten "voor zegels, registratie enz. zijn betaald, dan blijft er p.m. "f 80 ter beschikking voor de installatie van den bewoner "(eigenaar). Onder die installatie versta ik klein vee of pluim"gedierte, veevoeder voor den eersten tijd, zaad, planten enz., "wat het gezin blijkt te behoeven om den grond te beplanten, "enz. En nu ontvangt de geldschieter eene hypotheekakte voor "het gestelde bedrag, rentende voor hem hoogstens $3 \frac{1}{2}$ ten hon"derd, of zooveel minder als door hem wordt verlangd. De "eigenaar betaalt an den Bond echter 4 pCt., d. i. f 40 , plus "de assurantiepremie voor 't huis tegen $\mathrm{f} 800$, zijnde 80 cents "'s jaars; zoodat hij wekelijks ann den beheerder der stichting "te betalen heeft, de eerste 24 weken 79 cts, en de volgende "28 weken 78 ets. Daarvoor heeft hij een vrijstaand huis met "een bunder grond in bezwa ard eigend o m ${ }^{2}$ ). Het verschil "tusschen wat de hypotheekhouder eischt en de Bond int, "vormt het fonds van beheer, waruit beplantingen, "wegen, administratiekosten, en alles wat de geheele stichting "ten goede komt, wordt betald. Voor het onderhond, "t welk "in de eerste jaren natuurlijk weinig of niets zal bedragen,

1) Eene afbeelding en beschrijving dier woningen vindt men o. a. in B. v. R.'s artikel in het «Handelsblad van 21 April 1895, 3e blad: «Het Hofveld te Apeldoorn», waarop de aandacht wordt gerestigd tot anvulling van het in den tekst gezegde.

$\left.{ }^{2}\right)$ Nog zij opgemerkt dat cle op eenige meters van elkaar gebouwcle woningen alle aan den stratweg of atan de op het terrein aangelegde wegen zijn gelegen en dat tusschen elk tweetal woningen eene goed drinkwater opleverende pomp is geslagen. 
"kan de bewoner deelhebber worden in een fonds, waaran hij minstens ') 1 cent per dag moet bijdragen. In vrije uren, op vrije "dagen, of als hij geen werk heeft (want hij is en blijftwerk"man, arbeider), vindt hij productief werk op eigen grond. "Vrouw en kinderen zorgen voor het klein vee, voor den oogst, "voor den tuin ${ }^{2}$ ), en helpen op den akker, als tijd en gele"genheid dat toelaten of eischen. Wie nu werken kan en wil; "wie nu matig en spanrzaan leert worden; wie nu begrijpt dat "alles wat hij doet voor hem is en voor zijn gezin; wie iets "verder leert zien dan den dag van heden, en dat alles komt "geleidelijk, die zal al spoedig, zeg over twee jaar, iets "kunnen gaan sparen. Maar ik werd te uitvoerig, wanneer ik "zon willen omschrijven welken invloed dat wonen en werken heeft "op de zedelijke en intellectueele ontwikkeling, op de zelfstan"digheid en 't besef van verantwoordelijkheid voor zich en de "zijuen, afgescheiden van het materiëel zooveel betere leven. "Laat ik er mij dus nu toe bepalen nog ten slotte te doen "opmerken dat op deze wijze, met elke 1000 gulden rentegevend "belegd in vast goed, een arbeidersgezin tevreden, ja gelukkig "is gemaakt, en een H. A. woesten grond ontgonnen wordt, "alles mede van belang voor maatschappij en Staat."

Dat uitvoerig citat scheen nuttig om goed te doen zien wat op het Hofveld wordt verricht en welk doel wordt beoogd.

"Zedelijke verheffing", zoo wordt in den aanvang van dat artikel gezegd en daarop willen we nog wijzen, "en verbetering "van den economischen toestand worden beoogd bij de ontginning "van heidegrond, die begint met een goede woning.... En "wanneer men nn, door die woning op den zoo goedkoopen "heidegrond te bouwen, het huis zooveel minder kostbaar kan "doen zijn, en tevens den bewoner eeu bloem- en moestuin, "een boomgaard, een bleekveld, een akker voor eigen voeding "en voor klein vee, eenig hout enz. kan verschaffen, tegen "eene betaling, hoogstens gelijk, maar meestal minder dan die "voor kamers of huurhuisjes wordt vereischt, dav is er waarlijk

1) Waarom hij meer zou betalen zoo een cent voldoende is, is niet duidelijk.

2) Vóór elke woning gelegen en met bloemen, vruchtboomen en planten, peulvruchten enz, bezet. 
"niet zooveel begrip noodig om eene keuze te doen en een "besluit te nemen Maar wanneer men daarbij weet, zooals do "ondervinding leert, dat die zoogenaamde onvruchtbare heide "zoo dankbaar is voor doelmatige behandeling, dat de arbeid "er aan besteed hoogst loonend is in toenemende mate, dan "moet men zich verwonderen over de aarzeling, om overal "waar daartoe gelegenheid bestaat, stichtingen te doen verrijzen "als die te Apeldoorn."

Bevordering van "Bescheiden Heidegeluk" heet de Oranjebond van Orde zijn streven $\left.{ }^{1}\right)$. En nit de aangehaalde woorden, welke met vele andere uit meerdere stukken zouden kunnen worden aangevuld ${ }^{2}$ ), blijkt met hoeveel warmte de heer Bruijn van Rozenburg naar de bereiking van dat doel streeft.

Op 14 Mei 1894, zie "Sta Pal!" van $19 \mathrm{Mei}$, waren 18 woningen op het Hofveld voltooid en alle betrokken en werd de stichting met zekere plechtigheid en met het brengen van hulde aan den ontwerper en uitvoerder Bruijn van Rozenburg ingewijd, terwijl tevens besloten werd met den bouw van woningen op het Hattemsche veld een aanvang te maken. Reeds werd gezegd dat er thans in 't geheel 32 woningen gebouwd en betrokken zijn.

Ons eerste bezoek gold "Ous Huis", de nieuwe op $25 \mathrm{Mei}$ 1896, tegelijk met de later te bespreken "Erica-stichting", ingewijde stichting op het Hofveld "). Voor de inwijding zelve en de daarbij door den nieuwen beheerder van het Hofveld $L$. W. Th. Schmidt ${ }^{*}$ ) en door anderen gesproken woorden, wordt

1) Zie, behalve het Jaarverslag, o. a. «Sta Pal!» van 14 Oct. 1893 en daarin ook "Onze Circulaire in zake heide-ontginning*, nuttig om te doen zien van welke beginselen de Bond uitging, hoe zị n eplan van uitvoering was, wat de door iederen verkrijger eener hoeve te onderteekenen hypothecaire schuldbekentenis hoofdzakelijk zal bevatten, enz.

$\left.{ }^{2}\right)$ Ten einde niet te uitvoerig te worden, vermelden wij slechts een cleel zijner menigvuldige, ter onzer beschikking gestelde stukken.

3) Zie over beiden o. a. \&Sta Pal! van 14 December 1895, en het artikel "de dubbele inwijding" in "Sta Pal!" van 30 Mei jl.

4) De heer Bruijn van Rozenburg toch had reeds in Juli 1895, zie Jaarverslag p. 7, «om voor hem zeer overwegende redenen» tot groot leedwezen van 's Bonds bestuur, zijne betrekking van be- 
verwezen naar "Sta Pal" van 30 Mei. Maar om te doen zien wat "Ons Huis" is, wordt uit het jaarverslag, p. 9, het volgende overgenomen.

"Reeds langen tijd was de dringende behoefte gebleken om "aan de stichtingen van Hof- en Hattemsche veld haar nood"zakelijk complement te geven door de oprichting van een "lokaal waarin den bewoners de gelegenheid zou worden ge„boden elkander en zoowel de onderlinge als ieders speciale "belangen op aangename en nuttige wijze te leeren kennen; "het zoo noodige gemeenschapsgevoel aan te kweeken; eenvoudige "kennis van velerlei wetenswardigs op te doen; aan de aan"komende meisjes onderricht in vrouwelijke handwerken, aan "de kleine kinderen der velden, bij verplichte afwezigdeid der "ouders, een veilig plekje, in een woord, om aan de stich"tingen een passend en aan de eischen beantwoordend, centraal "vereenigingspunt te geven. Dus rijpte het plan tot den bouw "van $\mathrm{Ons} \mathrm{Hu}$ is ${ }^{1}$ )." Dank aan veler medewerking, o. a. van de "Kwart-gulden vereenigingen", kringen van belangstellende dames, an wier zeer gewaardeerde medewerking in het verslag en o. a. in "Sta Pal" van 23 Mei $1896^{2}$ ) herhaalde malen hnlde wordt gebracht, werden de benoodigde gelden gevonden en, gelijk reeds werd gezegd, op 25 Mei jl. kon het eenvondige, nette gebouw worden ingewijd. Het hevat eene beheerderskamer een vertrek voor bergplaats, tevens kautoortje voor den opzichter of concierge, een oud-Indisch militair, en eene flinke zaal.

heerder nedergelegd. $\mathrm{Om}$ zijne vele verdiensten jegens den Bond, benoemde de algemeene vergadering van 14 December 1895, zic Verslag p. 10, hem tot Eere-voorzitter van den Bond. Zijne belangstelling in de Bonds-stichtingen blijft echter onverminderd blijkens zijne herhaalde bezoeken en raadgevingen en zijn nog voortdurend optreden in de pers.

1) In vele opzichten zou men kunnen zeggen dat daar Toynbeewerk wordt verricht.

$\left.{ }^{2}\right)$ Blijkens de «Staatscourant van 13 October jl. zijn de Statuten goedgekeurd der «Kwartgulden-Vereeniging voor Heide-ontginning* te 's Gravenhage, welke Vrouwenvereeniging zich ten doel stelt den «Oranjebond van Orde» geldelijk te steunen en een band to vormen tusschen de verschillende liring-comités, tot nu toe, ten getale van 25 , hier en daar bestaande. 
Over dag doet die zaal dienst als kinder-bewaarplats. Tijdens ons bezoek vonden wij er eene vriendelijke onde vrouw, die eenige kleintjes met allerlei spellen angenaan bezig hield. In die zaal is ook eene kast met boeken, welke aan de bewoners van het Hofveld worden uitgeleend. In die zaal werd onze aandacht ook getrokken door de "Spandoos," eene inrichting wanrover het Jaarverslag zwijgt omdat de Spaarkas eerst in April van dit jaar in werking trad. "Sta Pal" van 11 Juli wijdt danran een artikel, aan hetwelk het volgende wordt ontleend. "De Sparkas is een tafeltje, waarop een kastje, voorzien van 4.8 gleuven, waaronder 4.8 hokjes met nummers overeenkomende met de nummers der perceelen." In de hokjes I-32, overeenkomende met het aantal thans bezette woningen, werd, als "lokkebrood" bij den aanvang een kwartje, geschenk van de fondsen van beheer, in elk hokje gestort. Die kwartjes werden als eerste inlage in ieders spaarboekje ingesehreven. Aan de bevolking werd bekend gemaakt dat zij dagelijks hare spaarpenningen kan inbrengen en dat deze rente zullen dragen. Tweemalen per week ledigt de beheerder de Spaarkas, brengt de bedragen in zijn boek over, en neemt de gelden mede naar huis en schrijft maandelijks de rente bij, berekend ì $\frac{1}{2}$ cent per vollen gulden en per volle maand. Nadat die instelling drie manden in werking was geweest, diende de beheerder aan het Bondsbestuur een verslag daarover in. Daaruit bleek dat 13 van de 32 bewoners een bedrag van 4.6.02: hadden hespard. De uitersten wareu 1 cent en f 15.35. De beheerder doet, terecht, zijn best om het sparen an te moedigen. Het verbinden eener Spaarkas an de stichting komt ons zeer goed gezien voor. Het volgend Jaarverslag zal wel meerdere mededeelingen daaromtrent bevatten, o. a. hoe de renten worden gevonden.

Achter "Ons Huis" is eene speelplaats voor de kinderen; vóór een tuintje, waar naast bloemen enz. de welig groeiende Lathyrus Silvestris Wagneri, hier als proef geteeld, de andacht trekt.

De heer Bruijn van Rozenburg heeft van dat, volgeus hem uitstekend vocdergewas, dat door het veo, zoowel groen als droog, gaarne genuttigd wordt, de grootste verwachtingen en bespreekt het telkeus, zie b. v. "Nieuwe Apeldloornsche Courant" 
van 21 April 1894, "Sta pal" van 9 Nov. 1895, 30 Mei 1896 , enz. Blijkens het Jaarverslag, p. 7., stelde het hoofdbestuur van den Bond hem in staat de op kleine schaal goed geslaagde proefneming op grooteren voet te herhalen. Daarvoor werd een deel van het Hofveld bestemd. Die grond werd omgezet en bemest en gedeeltelijk met eigen gewounen, gedeeltelijk met uit Beieren ontboden zaad bezaaid, en men zag er nu het gewas in onderscheideu stadiën van ontwikkeling. De deugdelijkheid onzer Lathyrus bleek onbetwistbar, zoo zegt het verslag, door het onderzoek van een Apeldoornsch chemicus en door eene analyse aan het Rijkslandbouw-proefstation te Wageningen.

Ongetwijfeld zou het te hopen zijn, in de eerste plaats voor de bewoners onzer heidegronden, dat de groote verwachtingen welke de heer Bruijn van Rozenburg omtrent de Lathyrus koestert. verwezenlijkt mochten worden, omdat wij daardoor een uitstekend vuedergewas rijker zouden worden. Ik moet er echter op wijzen dat ik, van Apeldoorn naar Frederiksoord vertrokken teneinde de Koloniën der Maatschappij van Weldadigheid weder eens te bezoeken, er darar wel met ingenomenheid, maar toch met minder enthousiasme over hoorde spreken. De Directenr der Maatschappij, Job van der Have, had er te Frederiksoord eene proef op vrij groote schaal mede genomen en het gewas stond welig en werd gaarne door het vee gemuttigd. De Directeur der Gerard Adriann van Swieten Landbouwschool to Willemsoord, Marissen, in wiens proeftuin ik het gewas zag staan, zei mij dat hij er een schimmelplant op had ontdekt, mogelijk gevolg van het gebruiken van minder goed, eenigszins verbasterd zaad. Hij vertelde echter dat, zoo telkens versch zaad uit Beieren zou moeten worden ontboden, dit te duur zou uitkomen. Beiden zouden echter de proeven voortzetten omdat zij aan het gewas waarde hechtten.

Buiten de Lathyrus zag ik op de akkers van het Hofveld menig ander gewas prijken. Zeer merkhaar was echter het verschil tusschen den eenen akker en den anderen. Waar men xich stipt had gehouden aan de wenken van den beheerder orn anvankelijk geeu grooter uitgestrektheid to bewerken dan door den Bond in bebouwharen toestand gebracht en bewerkt was, stond het gewas welig. Daarnaast zag men soms cen vold dat 
er treurig uitzag omdat de bewoner, meenende dat hij veel zou oogsten zoo hij slechts veel uitzaaide of pootte, een te groote uitgestrektheid in bewerking had genomen, zonder voor behoorlijke bewerking en bemesting te zorgen.

Over het geheel maakte echter het Hofveld met zijne nette woningen, zijne tevreden bevolking, zijne met velerlei gewassen bezette akkers, een angenamen indruk, omdat men er ziet wat in korten tijd, mits de zak goed worde aangevat, van onze heidevelden is te maken.

Of echter de geheele zaak goed is opgezet en geregeld? of alles an de misschien wel wat hong opgeschroefde verwachtingen zal beantwoordeu? Daaromtreut bestaan bij mij nog wel eenige twijfelingen. Ik nam de vrijheid deze aan den heer Bruijn van Rozenburg mede te deelen. Hij meende alle mijne bezwaren te kunnen wederleggen en verwees telkens naar door hem geschreven stukken ter wederlegging van meer of min soortgelijke bezwaren, door anderen in het midden gebracht. Van eenige dier bezwaren en van zijne wederlegging daarvan worde hier melding gemaakt.

Bij velen in Apeldooru zijn de stichtingen van "Bescheiden Heidegeluk" van den Oranjebond van Orde, speciaal die op het Hofveld, nict populair. Inzonderheid het gemeentebesturur gaf tot nu toe niet het allergeringste bewijs van belangstelling. De heer B. v. R. klaagde daarover meermalen in zijne stukken. Zie o. a.: "Sta Pal!" van 1893, no 23, "de Telegraaf" van 26 Januari 1894, enz. Velen schijnen te vreezen dat de stichting op het Hofveld aanleiding kon geven om behoeftigen naar Apeldoorn te lokken. Daartegen wordt gewezen op de bepaling dat voorwaarden voor vestiging op het Hofveld of Hattemsche veld zijn: dat men miustens twee jaren ingezeten der gemeente zij en als arbeider een vast bestaan hebbe. Bovendien worden slechts zulke gezinnen geplaatst, welke door het bestuur van den Bond geschikt worden geacht voor het doel hetwelk men zich voorstelt. Met zulke waarborgen schijnt er inderdaad weinig grond voor de vrees dat de stichting behoeftigen naar de gemeente zou lokken.

Mij dunkt dat tegen de zaak bezwaren van neer gewicht zouden kunnen worden aangevoerd. Het zeer zeker lofwaardig 
doel van de stichters ${ }^{1}$ ) was den bewoners eene flinke, in een gezond oord gelegen woning voor weinig geld te bezorgen en hen in de gelegenheid te stellen uit de opbrengst van deu danrbij behoorenden grond humne inkomsten te vermeerderen. Zij waren evenwel overtuigd dat een gezin van de opbrengst vau een hectare heidegrond niet zou kunnen bestaan en stelden daarom als eisch dat het hoofd des gezins als vaste arbeider zijn eigenlijk levensonderhoud moest verdienen en de opbrengst zijner hoeve slechts als bijzank, als middel tot verbetering zijner sociale positie zou beschouwen. De stichters wisten bovendien dat de heide, om goede opbrengsten te kunnen opleveren, goed bewerkt en voldoende bemest moest worden en raadden daarom de bewoners ernstig aan aanvankelijk niet meer te beteelen dan het een vijfde van hun grond dat door den Bond in bebouwbaren toestand was gebracht en slechts trapsgewijze verder te gaan naarmate zij den grond verder zouden hebben bewerkt en over voldoenden mest konden beschikken. Uitmuntend. Maar zoo een eigenwijs persoon, misschien aangelokt door de artikelen van Ericus in het "Nieuws van clen Dag", na korter of langer tijds meent wèl van de opbrengst van zijn grond te kunnen leven en zijn ambacht verlaat om zich geheel aan de beteeling van zijn grond te wijden? Mij werd geantwoord dat hij dit niet licht zou doen omdat hij begrijpen zou dat het hem dan moeilijk zou vallen de wekelijks door hem versehuldigde rente op zijn hypotheonire schuld te betalen en hem dan het gevaar boven het hoofd hing dat hij dan, krachtens de bepalingen der door hem onderteekende hypothecaire schuldbekentenis, gedwongen zou kunnen worden de hoeve te ontruimen. Dank aan de welwillendheid van een der hypotheekhouders, mocht ik inzage bekomen van eene zoodanige schuldbekentenis. Maarin staat uitdrukkelijk dat de debiteur zich bereid verklaart in gelijke wekelijksche termijnen over het hem geleende kapitaal een interest van 4 pCt. in het jaar te zullen betalen ${ }^{2}$ ), verklaart in gebreke te zullen zijn

1) Het «Handelsblad» van 5 Juli 1895 sprak dan ook terecht van «Een stichting die steun verdient».

$\left.{ }^{2}\right)$ Boven zagen wij waarom de Bond 4 pCt. int, doch de geldschieter zich gewoonlijk met $3 \mathrm{pCt}$. tevreden stelt. 
"door het enkel verloop van den bepaalden termijn", en dat bij "gebreke van behoorlijke voldoening der hoofdsom ') of van de betaling der verschuldigde interesten de crediteur onherroepelijk zal zijn gemachtigd de verbonden goederen in het openbaar te doen verkoopen" enz. Ik wil gaarne aannemen dat men door dergelijke bepalingen de debiteuren voldoende in zijn macht heeft en dat dus de geldschieters op het Hofveld gevrijwaard zullen zijn van een ramp als b.v. de geldschieters van de Coöperatieve Bouwvereeniging "Vooruit" te 's-Gravenhage trof, die hun geld grootendeels te loor hebben zien gaan. Maar bedoelde bepalingen beletten $\mathrm{m}$. i. den onverstandigen onder de bewoners van het Hofveld toch niet geheel on zijn ambacht te verlaten of zijn land slecht of althans op min doelmatige wijze te bewerken.

Dat dit laatste nog al eens voor $\mathrm{kwam}$, wordt ook erkend op p. 7 van bovenvermeld jaarverslag van den Bond, waar sprake is van een, zij het gering tekort op het versehuldigd rentebedrag en van het vertrek van twee gezimnen, "die hun eigendom niet op waarde stelden".

We laten dit en andere punten evenwel verder rusten en komen tot ons hoofdbezwaar tegen de geheele zaak. Het betreft de to ekenning van eigendom, iets waartegen Jhr. Mr. D. O. Engelen reeds in 1.893 in het "Sociaal Weekblad" opkwam, zich o. a. beroepende op het gebeurde met de bekende "cité ouvrière" te Mühlhausen, en dat door den heer Bruiju vall Rozenburg met warmte wordt verdedigd in "Sta Pal" van 2 December 1S93, $\mathbf{1}^{\circ} 24$ en in meerdere stukken ${ }^{2}$ ). Hij verdedigde dat beginsel, waaraan hij voor zijn doel: verbetering van deu economischen toestaml der mindere klasse, groote warde hedht, opuieuw tegen de opwerkingen, welke $\mathrm{ik}$ mij veroorloofde danr

1) Daaromtrent is nog bepaald, dat deze ten allen tijde aflosbaar en opeischbaar zal zijn, wanneer ran de eene of andere zijle ten minste drie maanden te voren tegenzijds opzegging zal zijn getlaan en op welke hoofdsom door den debiteur naar zijne keuze zal kunnen worden afgelost, mits deze aflossing geschiede in ronde sommen van niet minder dan honderd gulden».

2) 0. a. in de "Apeldoornsche Courant" van 23 Juni 1894, in de «Nieuwe Apeldoornsche Courant" van 30 Nov. 1895 en 3 en 10 Juni 1896, in «Sta Pal!» van 27 Juni jl. 
tegen in het midden te brengen. Natuurlijk, gelijk meestal in zulke gevallen, overtuigden wij elkaar niet. En aangezien het hier een voor de toekomst van den Oranjebond en zijn stichtingen zeer gewichtig beginsel geldt, zal ik mij de vrijheid veroorloven mijne bezwaren tegen die toekenning van eigendom hier te herhalen.

Wellicht zou kunnen worden volstaan met eene verwijzing naar hetgeen in "de Economist" van December 1888 in het artikel: "Iets over arbeiderswoningen" en ook in "Erica, Jaarboekje der Mij. v. Weldadigheid " van 1896 en 97 , bij de bestrijding van het denkbeeld der "Nieuwe Rotterdamsche Courant" om van de vrijboeren te Frederiksoord eigenerfde boeren te maken, tegen die eigendomstoekenning is aangevoerd. Daarheen voor meerdere bijzonderheden verwijzende, worde nu slechts op het volgende gewezen.

Op sociale gronden, en overtuigd van het hartverheffende lat er in gelegen zou zijn dat de arbeider aan zijne kinderen een eigendom zou kunnen nalaten, overtuigd ook dat van den arbeider-grondeigenaar niet te vreezen is dat hij communist of anarchist of vijand der maatschappelijke orde zou worden, zou ik hoogst gaarne voor iedereen uit de mindere klasse de gelegenheid willen geopend zien een eigen huis en hof te verkrijgen. Jarenlang ben ik dan ook een warm voorstander geweest van het denkbeeld dat de arbeider den individueelen eigendom van het door hem bewoonde huis moest kunnen verkrijgen. Nog blijf ik daaraan groote waarde hechten. Maar de bezwaren daartegen anngevoerd door de heeren vau Marken, Engelen en auderen, het gebeurde te Mühlhauseu, warar kennelijk de edele bedoelingen van den stichter der "eités ouvrières" niet gehandhaafd zịn kunnen worden, hebben mị, ik zei het reeds in "de Eiconomist" van December 1888, hoewel noode, ann het beginsel van gemeenschappelijk eigendom boven dat van individueel eigendom de voorkeur cloen geven. Hetgeen ik sedert dien tijd over het onderwerp las en hoorde, o. a. in Mr. J. Kruseman's pleidooi voor collectieven eigendom in het "Haudelsblad" van 23-2S Januari 1893, in het zoo belangrijk Nutsrapport over "het vraagstuk der Volkshuisvesting", (waarover zie o. a. Mr. J. A. Levy's artikel in het "Hamtelsblad" vau 26 April jl., waariu hij tegen de corn- 
missie opkomt voor den individueelen eigendom, en Mr. R. J. A. Patijn's recensie in "de Economist" van Mei jl.), en de treurige ondervinding opgedaan door de geldschieters aan de Hangsche Coöperatieve Bouwvereeniging "Vooruit", bevestigden mij sleehts in die meening.

Zij die, meenende eene goetle zaak te steunen, hun geld an "Vooruit" toevertrouwden, hebben moeten ondervinden dat enkele gebruikers van de wouingen dier vereeniging, hun voordeel doende met, waar het schijnt, onvolledige bepalingen in de statuten en voorwaarden van bewoning, spoedig geweigerd hebben huur of interest te betalen, voorgevende in de woning een onbezwaard eigendom te bezitten. Zoo iets, zei de heer Bruijn v. R., zou op het Hofveld niet kunnen plaats hebben omdat de bewoners zich bij het teekenen der hypothecaire schuldbekentenis verbonden hebben in wekelijksche termijnen en tot aan de aflossing toe den interest dier schuld te betalen en het bestuur het dus in de hand heeft den ualatigen debiteur terstond te doen vertrekken. Aangenomen, gelijk ook uit het op p. 7 van 's Bonds Jaarverslag gezegde mag worden opgemaakt, dat daarmede geen moeilijkheden zullen wordeu ondervonden, zoo blijven er toch andere bezwaren over.

Volgens de boven besproken hypothecaire schuldbekentenis erlangt de bewoner van het Hofveld eerst den onbezwarden eigendom van huis en hof na de geheele aflossing der daarop rustende schuld van f 1000 . Buitengewone gevallen, b.v. het bekomen eener erfenis, daargelaten, zal die aflossing wel slechts kunnen plaats hebben door het beleggen van gelden in de "Spaardoos" of in eene spaarbank 1). Boven, p. 830 , zagen wij, dat in de eerste drie maanden na de openstelling der gelegenheid tot sparen 13 van de 32 bewoners (dus nog niet de helft) bedragen hadden ingebracht, varieerende van 1 cent tot $f 15.35$. Gesteld dat er eenigen zijn die jaarlijks 50 à 100 gulden kunnen besparen, deze zullen om de 1 à 2 jaren 100 guldeu schuld kunnen aflossen en dus na 10 of 20 jaren onbezwaarde

1) Reeds in een zijner eerste artikelen over het onderwerp, in de "Nieuwe Apeldoornsche Courant» van 5 Juli 1893, sprak de heer Bruijn van Rozenburg van belegging in de spaarbank om «kapitaal te vormen tot aflossing van schuld». 
eigenaars zijn. Maar wanueer zullen de overigen het worden? Zou het daarom, zoo men individueelen eigendom wil, niet verkieslijk zïn geweest de zaak te regelen zooals bij vele hypotheekbanken het geval is en eene annuiteit te bepalen, waardoor tevens aflossing van het kapitaal in een vooraf bepaald aantal jaren wordt verkregen? $\mathrm{Nu}$ zal, meenen wij, voor zeer velen der bewoners het verkrijgen van een onbezwaard eigendom wel eene illusie blijven, terwijl de beheerder telkens lastige berekeningen zal hebben te maken. Boven zagen we toch dat de bewoners 80 cents 's weeks te betalen hebben, o. a. voor rente ad 4, pCt. 's jaars over hunne schuld van f 1000. De billijkheid zal dus eischen dat dat wekelijksch bedrag worde verminderd met de rente over elke f 100 welke door hen wordt afgelost. Welk een omslag zal dat geven, vooral zoo het antal gezinnen zich aanmerkelijk uitbreidt!

Tot nu toe, zie Jaarverslag p. 7, had men geen moeielijkheden met de weinigen die zich op het Hofveld vestigden en na korten tijd weder vertrokken. Maar hoe zal het gaan wanneer een bewoner weg wil of weg moet na eenige jaren lang het wekelijks verschuldigde stipt te hebben aangezuiverd en zijn land goed bewerkt te hebben, zonder echter iets van zijne schuld te hebben kunnen aflossen? Hoe wanneer hij wel een deel daarvan had kunnen afbetalen? Hoe wanneer de man overlijdt en de weduwe niet op de hoeve kan blijven? Hoe zal in zulke gevallen worden gewaardeerd wat in billijkheid aan deu man of zijne erven, wat aan den Bond toekomt? Zouden vele dier voorziene moeilijkheden niet worden voorkomen zoo van collectieven in plaats van individueelen eigendom sprake was?

Maar gesteld meerdere bewoners van het Hofveld krijgen na korter of langer tijd de volledige beschikking over huis en grond, dan voorzien we, gedachtig aan hetgeen elders gebeurl is, andere moeielijkheden. Bij het bouwen op het Hofveld had men ook een hygiënisch doel. Men wilde den arbeider eene goed gebouwde, goed ingerichte woning op het open veld, men wilde hem licht en lucht geven. Heeft hij de geheel vrije beschikking over huis en grond, wie kan hem op den duur beletten zijn huis te bederven, zijn grond vol te bouwen of te versnipperen? Dit kan alleen worden voorkomen, wanneer Econ. 1896. 
de vereeniging eigenaresse blijft, de bewoners slechts andeelhouders in de vereeniging worden.

Doch al genoeg over dit punt. In vele opzichten hoogelijk ingenomen met het van gezonde philanthropische denkbeelden uitgaande streven van den Oranjebond van Orde, meenden wij onze waarschuwende stem te moeten doen hooren tegen het ten opzichte van de bewoners van het Hofveld aangenomen begiusel om hen reeds dadelijk eigenaars te heeten. Wij vreezen dat de Bond zich daardoor voor het vervolg groote moeilijkheden schept, en bij de bewoners illusiën opwekt, welke voor verreweg de meesten hunner nimmer verwezenlijkt zullen kunnen worden. Een waarschuweud woord scheen te eer noodig un sprake is van het in het leven roepen van soortgelijke stichting bij Amersfoort en daarbij misschien ook aan eigendomstoekenning wordt gedacht '), en het ons wenschelijk voorkomt dat men de zaak nogmaals rijpelijk overwege alvorens daartoe te besluiten. Het scheen ook weuschelijk na de van groote ingenomenheid met het streven van den Bond getuigende, in het "Dagblad van Z.-H. en 's Gravenhage" overgenomen artikelen in het "Handelsblad" van 27 en 29 September jl., waarin geen enkele aanmerking op het in het Hofveld gevolgde stelsel wordt gemaakt en dus geheele instemming met de gevolgde beginselen mag worden verondersteld.

Misschien ware het verkieslijk woningen en gronden, als die op het Hofveld, slechts in huur of in erfpacht uit te geven. Maar acht men het, met het oog op het streven van den Bond naar verbetering van de positie, naar verheffing, naar verruiming van den blik der mindere klasse, beter het vooruitzicht op eigendomsverkrijging te openen, dan schijnt bij zulke stichting aan collectieven boven individueelen eigendom de voorkeur te moeten worden gegeven.

De stichting op het Hofveld hield ons zoolang bezig, dat wij aan de overige stichtingen van den Oranjebond, die trouweus niet tot soortgelijke opmerkingen aanleiding geven, slechts enkele regelen kunnen wijden.

1) Blijkens *Sta Pall» van 27 Juni, p. 428, blijft dit voorshands nog een open vraag. 
Onder geleide van den heer Bruijn van Rozenburg werd door mij ook de Erica-Stichting in de Wormingermate onder Apeldoorn, met hare vijf nette hoeven, elk met $4 \frac{1}{2}$ hectaren grond, bezocht. Wat de Bond met die Stichting voor had, leert het jaarverslag, p. 4. "De Bond wilde proefondervindelijk onderzoeken of kleine heidehoeven, geheel daarvoor ingericht, bij matige maar zekere rentabiliteit, een bestaan kunnen verschaffen aan oppassende arbeiders, zij het niet als uitsluitende, dan toch als voornaamste inkomst-bron. De heer Bruijn van Rozenburg slaagde er in een terrein van p. m. 25 hectaren goeden en goed gelegeu heidegrond in de Wormingermate onder Apeldoorn voor dit doel aan te koopen. En binnen enkele weken gelukte het den Bond het benoodigd kapitaal te vinden voor de stichting van vijf heidehoeven, naar het ontwerp van dien heer, gelukte het hem ook den heer In 't Velt, den beheerder van het Hattemsche veld, bereid te vinden het heheer dezer nieuwe stichting, die den naam van Erica-stichting ontving, op zich te nemen, en den heer Dr. A. M. Prins, Rijks-landbouwleeraar te Deventer, te winnen voor de deskundige leiding van dien zeer gewichtigen arbeid.

Aldus, van alle zijden goed gewapend, werd de taak aanvaard en toen November daar was, bood deze heidevlakte reeds een vriendelijk en veelbelovend kijkje op een vijftal goed gebouwde, bevallige boeven, door groote stukken mooi weiland omgeven, en hadden reeds drie gezinnen met have en goed in de Wormingermate onderdak gevonden" !)

Voor verdere bijzonderheden wordt naar het Jaarverslag, naar het weekblad "Sta Pal" en naar de bieronder te bespreken, van het Landbouw-Comité nitgegane stukken verwezen Hier zij nog slechts het volgende aaugeteekend. Door het geheele terrein is een flinke weg aaugelegd. Voor afwatering is goed gezorgd. De woningeu, grooter dan die op het Hofveld, en geheel op het boerenbedrijf ingericht, zien er flink uit. Bij iedere woning behooren $4 \frac{1}{2} \mathrm{H}$. grond, waarvan de helft voor rekening van den Bond in bebouwbaren toestand werd gebracht

1) Wat die stichting kostte, vermeldt «Sta Pal ! van 22 Augustus en tevens dat de «Kwartjes-Vereenigingen» in minder dan 3 jaren f 8000 in de kas van den Bond stortten. 
alvorens de hoeven werden betrokken. De bewoners werden met zorg uitgekozen onder hen die met veehouding en landbouw bekend waren. De bedoeling is de hoeven in erfpacht uit te geven. Maar aanvankelijk zijn de bewoners huurders en wel in den anvang voor eene zeer geringe huursom, totdat ondervinding omtrent de rentabiliteit zal zijn opgedaan. Daarom werd ook, volgens een ontwerp van Dr. Prins, eene der hoeven voor eene proefboerderij bestemd, geheel gericht op veehouding en intensieve cultuur, en daarop een zetboer geplaatst, die geheel de leiding van Dr. Prins volgt.

Hoe gunstig deze deskundige over de Erica-stichting denkt en wat hij van dergelijke stichtingen tot verbetering der sociale toestanden verwacht, leze men in zijne "Memorie" opgenomen in "Sta Pal" van 9 Nov. 1895.

Hoewel drie der hoeven reeds in November van het vorig jaar betrokken waren, had de plechtige inwijding der "EricaStichting", tegelijk met die van "Ons Huis" op het Hofveld, eerst op 25 Mei van dit jaar plaats. De beschrijving dier plechtigheid, het relaas der daarbij uitgesproken redevoeringen vindt men in "Sta Pal" van 30 Mei l.l.

De zaak bestaat eerst te korten tijd om reeds over hare levensvatbaarheid, over hare al of niet te groote kostbaarheid te kunnen oordeelen. Met zorg voorbereid, door deskundigen geleid, met toewijding en tact bestuurd, schijnt zij wel kaus van slagen te hebben. In elk geval geldt het eene belangrijke proef, welke algemeene belangstelling verdient, en welker welslagen wij van harte wenschen.

Nog korter dan met de Erica-Stichting mogen wij ous bezighouden met eene andere stichting van den Oranjebond van Orde: "De Utrechtsche Arbeidskas", opgericht in 1893. (Zie "Sta Pal" van 22 en 29 Juli). Het afzonderlijk gedrukt Reglement dier Kas wordt voorafgegaan door eene breede Inleiding. Wij nemen de eerste woorden daarvan over omdat daarin duidelijk wordt gezegd welk doel wordt beoogd. "Onder de pogingen, die de Oranjebond van Orde in het werk wil stellen om hen, die onder de economische maatschappelijke misstanden gebukt gaan, van dien last te ontheffen, moest, naar zijn inzien, in de eerste plaats een streven in aanmerking komen, om den knappen, ordelievenden, gezeten werkman te verzekeren 
tegen de gevolgen der zich periodiek herhalende werkloosheid, die op zijn geldelijken toestand van zoo uiterst nadeeligen invloed zijn, en juist hierdoor zooveel gevaar opleveren èn voor zijn maatschappelijken èn voor zijn zedelijken ondergang." Daarom, zoo wordt verder gezegd, meende de Bond goed te doen een verzekeringskas tegen de gevolgen vau werkloosheid in het leven te roepen. Een Arbeidskas, zoo luidt het verder, "moet in democratischen zin worden opgebouwd", zij "behoort het vertrouwen van den werkman te genieten, zijn liefde te hebben. IIij moet in haar angelegenheden worden gekend". Van die beginselen is bij het ontwerpen van het Reglement uitgegaan. Ten einde zekerheid te hebben met de zaak in den geest der werklieden te handelen, heeft de Bond zich in betrekking gesteld met den "Bestuurdersbond der Werklieden-vereenigingen." Dat overleg heeft tot omwerking van het eerste ontwerp geleid, doch, ten blijke dat overeenstemming is verkregen, is nu ook het gepubliceerde Reglement door het Bestuur van dien Bestuurdersbond voor gezien mede onderteekend.

De "Arbeidskas" bestaat echter nog slechts op het papier. Blijkens 's Bonds Jaarverslag, p. 10, bleef zij "het geheele jaar in onvrijwilligen slaap verzonkeu." De Bond vergat echter de zaak niet en ouderwierp het Reglement an het oordeel van Mr. H. S. Veldman te Groningen, "die o. a. door een reeks van artikelen in het "Alg. Handelsblad" getoond heeft een onvangrijke en ernstige studie van dezen tak van het verzekeringswezen gemaakt te hebben." Diens critische beschouwing, vermeerderd met enkele opmerkingen van 's Bonds Voorzitter, is in Maart jl. door den Bond gepubliceerd. Mr. Veldman heeft heel wat, door den heer Hora Siccama gedeeltelijk toegegeven aaumerkingen op het Reglement, maar eindigt toch met deze woorden, met welke wij gaarne instemmen: "De Oranjebond heeft een goed werk rerricht door de oprichting der kas. Ik wensch den Bond geluk met den moed, dien hij heeft getoond door de netelige materie der werkloosheid aan te durven en ik hoop van harte dat hij met zijn poging succes mag hebben."

Datzelfde succes zij den Bond toegewenscht met zijn onderscheidene pogingen tot verbetering der sociale toestanden, waarvan hierboven het een en ander werd medegedeeld. Al weerhielden wij in enkele opzichten onze alummerkingen uicl, 
in ' $t$ algemeen betuigen wij zeer gaarne te sympathiseeren met het edel, rerstandig philanthropisch streven van den Oranjebond van Orde.

In het bovenstaande was uitsluitend sprake van den Ora n jebond van Orde omdat wij in de gelegenheid zijn geweest met de werking van dien Bond eenigszins in bijzonderheden bekend te worden. Hen die van die werking en teveus van die van andere vereenigingen van meer of min soortgelijke strekking en ook van pogingen van particulieren om te geraken tot verbetering der sociale toestanden, meer willen weten, verwijzen wij naar een drietal, van het $\mathrm{Nederlandsch} \mathrm{Landbouw-Comité}$ nitgegane publicatiën. $1^{0}$. "Heide-ontginning en grondverbetering als middel tot verbetering der sociale toestanden." (Amsterdam, J. H. de Bussy, 1895). 20. "Verslag van de bandelingen, verricht door het Nederlandsch Landbouw-Comité, over het jaar 1895." $3^{\circ}$. "Verslag van de Meeting ter nadere bespreking van het door het Ned. Landbouw-Comité vastgestelde rapport in zake heide-ontginning en grondverbetering als middel tot verbetering dersociale toestanden, gehouden te 's Gravenhage, 20 Mei $1896 \%$. (Amst., de Bussy, 1896).

Het eerste stuk is het uiterst interessant en leerzaam rapport van "de commissie vontginning" uit het Ned. LandbouwComité", voorzitter de heer F. B. Löhnis, thans Inspecteur van het landbouw-onderwijs, vroeger jarenlang Directeur der Maatschappij van Weldadigheid en als schrijver over landbouwzaken den lezers van "de Economist" genoegzaam bekend. Het rapport vangt met de volgende woorden aan: "No in den laatsten tijd verschillende vereenigingen zijn tot stand gekomen of in wording zijn ter bereiking van heide-ontginning en grondverbetering als middel tot verbetering der sociale toestanden, meenden wij goed te doen dit rapport aan te vangen met eene uiteenzetting van het doel dezer vereenigingen, en wel in deze volgorde:

10. "Oranjebond van Orde", met het als onderdeel werkende "Centraal Comité der kwartgulden-vereeniging voor 
heide-ontginning". $2^{\circ}$. "Vereeniging door arbeid tot verbetering" in Friesland. 30. "Bond van Orde door Hervorming" in Groningen. $4^{\circ}$. Plan tot oprichting van eene "Maatschappij tot ontginning van heidegronden" met den heer Bertels als Directeur. 50. Plan tot het stichteu van "heidedorpen" door Ericus $6^{\circ}$. Als interessant voorbeeld van hetgeen door particulieren in deze richting is tot stand gebracht, wordt onder deze rubriek ook melding gemaakt van de proefneming van de heeren $\mathrm{Knuttel}$ en Heldring bij Hoenderloo."

Van dat alles wordt dan een beknopt critisch overzicht gegeven, zeer leerzaam on de verschillende doeleinden dier vercenigingen en mannen te leeren kennen.

Ten slotte van dat overzicht, p. 18, zegt de Commissie hel volgende, dat wij hier overnemen om te doen zien hoe de commissie die verschillende plannen in weinige woorden karakteriseert: "Uit bovenstaande niteenzetting blijkt, dat deze verschillende plannen, welke èn worden voorgesteld èn ten deele reeds in toepassing zijn gebracht, de volgende punten van overeenkomst en van verschil hebben.

" $I^{\circ}$. Het stichten van goede arbeiderswoningen ten platten lande, benevens het verschaffen van een stuk bouwland aan den arbeider wordt beoogd door: $a$. "den Oranjebond van Orde" (Hofveld te Apeldoorn); $b$. de Vereeniging: "Door Arbeid tot verbetering" in Friesland; $c$. de Vereeniging: "Bond van Orde door Hervorming" in Groningen, en $d$. door Ericus.

$" 2^{\circ}$. Het stichten van dorpen, bestannde in grootere en kleinere boerderijen op de heide, wordt anbevolen door Ericus en door den heer Bertels, terwijl ook de Oranjebond van Orde en de Bond van Orde door Hervorming de verwezenlijking van dit denkbeeld trachten te bevorderen.

$" 3^{\circ}$. Zoowel Ericus als de heer Bertels wensehen de werkloozen uit de steden naar de heide te verplaatsen ${ }^{1}$ ).

"4:. Voor boschcultuur wordt zoowel door Ericus als door

1) Beiden loochenden dit later. Zie 0. a. in de «Nieuwe Rotterdamsche Courant* van 16 Aug. jl., 2e blad, het artikel: «Heideontginning en grondverbetering», gewijd aan het Verslag der op 20 Mei te 's Gravenhage gehouden Meeting. 
den heer Bertels de heide te goed geacht. Beiden hebben openlijk verklaard, dat $\frac{9}{10}$ van allen woesten grond in Nederland bestemd moest worden voor bouwland.

"50. De Vereeniging "Door Arbeid tot verbetering" in Friesland 1) tracht zich, door locaal onderzoek, zooveel mogelijk op de hoogte te siellen van de oorzaken van bodemverwaarloozing en werkloosheid in de verschillende deeleo van haar gewest; door het bevorderen van nuttigen arbeid die schadelijke invloeden uit den weg te ruimen; de productiviteit van den bodem te verhoogen en op die wijze tevens werk te verschaffen."

"Voor eene juiste beoordeeling (zoo wordt verder gezegd), kunt het onze Commissie wenschelijk voor in het kort ua te gaan welke ondervinding op dit gebied bij ons te lande in vroeger tijden reeds was opgedaan en hoe men in het buitenland over het vraagstuk der ontginning der heide denkt." Wat dit lantste betreft, wordt dan gesproken over de resultaten verkregen in de "Heimath-kolonie Friedrich Wilhelmsdorf te Diiring en over de kolonisatie van het Bourtangerveen in Hannover aan ouze grenzen; over pogingen tot kolonisatie op de

1) Met welke de Commissie kennelijk het meest is ingenomen. Zie hare statuten, de telkens omtrent hare werking in de dagbladen roorkomende berichten, de door haar uitgegeven verslagen, o. a. «Overzicht omtrent de bij het Hoofdbestuur ingekomen antwoorden op de gestelde vraagpunten", welker doel was «den omvang en den aard der werkeloosheid in de onderscheiden Friesche gemeenten te onderzoeken, om daarna de middelen te overwegen waardoor verbetering mogelijk is». Zie in «Economist van 1895 , p. 828 , het verslag der, onder leiding van den voorzitter, Mr. W. J. van Welderen baron Rengers, gehouden algemeene vergadering van dat jaar. Zie ook het uit de "Leeuwarder Courant in het "Dagblad van Z. H. en 's Gravenhage» van 17 Dec. 1895 overgenomen artikel val den heer Albarda, waarin op den ruttigen werkkring der Vereeniging wordt gewezen, doch tevens geklaagd orer de weinige energie van sommige gemeentebesturen, die toch veel tegen de werkloosheid en tot grondverbetering zouden kunnen doen.

Let ook op de in de vergadering van de *Vereeniging voor Staathuish. en Statistiek» van 3 October over het Pachtcontract gevoerde debatten en speciaal op het bij die gelegenheid door den heer $\nabla$. W. Rengers gesprokene. 
heide vroeger in Pruissen en België aangewend, over het bedrijf onzer Maatschappij van Weldadigheid. De conclusie is, p. 22, dat die ervaringen stemmen tot voorzichtigheid ").

Vervolgens wordt er op gewezen dat in bijna alle beschaafde landeu, echter niet in Nederland, "eene wetgeving bestaat, welke ontginning tot bosch van bepaald aangegeven terrein beveelt of althans gemakkelijk maakt", en dat zoo iets ook bij ons wenschelijk zou zijn, en dat onze Heide-Maatschappij daarbij goede diensten zou kunnen bewijzen.

De Commissie, die erustig warschuwt tegeu kolonisatie van de heide door werkloozen ${ }^{2}$ ) en boeren, resumeert vervolgens, p. 27, hare meening omtrent de middelen die aangewend zouden kunnen worden om tot betere toestanden te geraken, en eindigt met eenige conclusiën aan het oordeel van het Landbouw-Comité te onderwerpen.

Die conclusiën zijn vermeld op p. 391 van "de Economist" van 1895 en worden daarom hier niet herhaald.

Het Landbouw-Comité vereenigde zich geheel met de beide eerste conclusiën, bracht eene kleine wijziging in de derde en hield de vierde aan "tot de behandeling van het te verwachten rapport over de bosch-cultuur."

$\mathrm{Na}$ nog gezegd te hebben dat aan het stuk meerdere belangrijke bijlagen zijn toegevoegd, o. a. eene Nota over het "Systeem Bertels", nemen wij afscheid van dit in ons oog niterst belangrijk, leerzaam, inhoudrijk rapport der "ontginuingscommisie."

Uit het tweede hierboven genoemde stuk, het Jaarverslag vall het Landbouw-Comité, wordt alleen aangeteekend, dat

1) Dit was ook de conclusie waartoe Professor Mavor kwam na zijn bezoek aan de Koloniën onzer Maatschappij ran Weldadigheid en aan andere meer of min soortgelijke instellingen in andere landen. Zie m. artikel: "Wat te doen tegen de Werkloosheid?" in «De Economist» van October 1894, blz. 673. Zie ook in het Novembernummer blz. 773 .

2) Zie daarover ook het bekende, in 1887 uitgebrachte rapport der commissie, benoemd tot het onderzoeken der mogelijkheid van heide-ontginning als middel tot werkverschaffing. Zie ook aEconomisto 1886 , p. 43,1887 , p. 1151,1894 , p. 670. 
men op p. 1 daarvan kan lezen tot welke beraadslagingen het rapport annleiding gaf.

Tot welke beraadslagingen dat Rapport op de Meeting van 20 Mei anleiding gaf, is in het kort vermeld op p. 4.87 van de Juni-aflevering van "de Economist," Die ex meer van verlangt te weten, leze het in de derde plaats hierboven vermelde Verslag dier Meeting. $\mathrm{W}_{\mathrm{ij}}$ zouden vreezen te uitvoerig te worden zoo wij daaruit nog veel mededeelden, herinneren dus slechts dat, na een inleidend woord van den voorzitter, den heer Bultman, en van den heer Löhnis als voorzitter der ontginnings-commissie, de conclusiën van het rapport besproken en gedeeltelijk bestreden werden, vooral door de vertegenwontdigers der drie bovengenoemde vereenigingen, de heeren Andreae, Bergsma en Kouijnenburg uit Friesland, den heer Koning nit Groningen, de heeren Hora Siccama en Prins voor den Oranjebond van Orde en door Ericus, terwijl zij verdedigd werden, behalve door den heer Löhnis, door de heeren Sickesz, van Rijckevorsel en Dinger. Er werden ook amendementen op de conclusiën voorgesteld. Maar gelukkig voor de vele leeken, onk dames, die de talrijk bezochte vergadering bijwoonden, gaf de voorzitter to kennen dat over de conclusiën niet gestemd zou worden, dus geeu amendementen daarop konden worden aangenomen. Gelukkig, zeg ik. Want velen, die, evenals met mij het geval was, de vergaderiug uit belangstelling bijwoonden, ontbrak het stellig aan de noodige kennis om met beslistheid voor of tegen die conclusiën te stemmen.

Moeten wij er ons toe bepalen voor de gevoerde debatten tot het Verslag der meeting te verwijzen, wij meeneu te mogen zeggen dat die debatten er toe hebben bijgedragen om het nuttig streven der drie genoemde vereenigingen beter bekend te maken en meer te doen waardeeren. $\left.{ }^{1}\right)$ Wij meenen ook te mogen zeggen dat de heer Löhnis ten slotte terecht mocht zeggen (zie Verslag p. 31) dat de indruk der gehouden bespreking deze was dat, ware tot stemuning over de conclusies overgegaan, de kolonisatie- en dorpsplanneu zouden zijn veroordeeld, doch sympathie zou zijn betuigd met ontginning van

1) Dit getuigde ook de Redactie van «Sta Pall» in haar nummer $\operatorname{van} 23$ Mei jl. 
daartoe geschikte heidegronden tot land voor arbeiders en, in 't algemeen gesproken althans, met het streven van de bedoelde vereenigingen. En met geheele instemming hoorde ik, oudstrijder voor het "samenwerkend handelen", oud-vijand van versnippering van wetenschappelijke en finauciëele krachten, zijn wensch dat die en andere soortgelijke vereenigingen mochten samenwerken tot verbetering, hij zei, der toestanden op het platteland, ik zeg der sociale toestanden in het algemeen.

Daaraan kunnen meetingen als die op 20 Mei 1896 in 's Gravenhage gehouden, ongetwijfeld bevorderlijk zijn.

Maar afgescheiden van dat desideratum, moet de lezing van het hierboven hesproken drietal stukken ernstig worden aanbevolen aan hen die willen weten wat bevoegde beoordeelaren zeggen over het streven van vereenigingen als de Oranjebond van Orde, de Bond van Orde door Hervorming en de Vereeniging door arbeid tot verbetering, en van mannen als Bricus en Bertels.

J. K. W. QuarLes van UFHord. 